NASA/TM-2002-211482
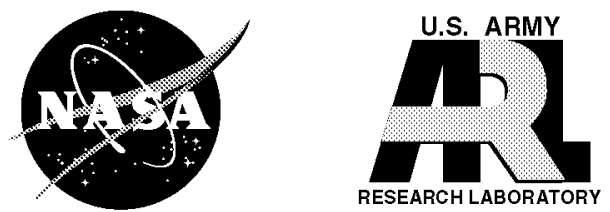

\title{
A Systems Approach to the Solid Lubrication of Foil Air Bearings for Oil-Free Turbomachinery
}

Christopher DellaCorte and Antonio R. Zaldana

Glenn Research Center, Cleveland, Ohio

Kevin C. Radil

U.S. Army Research Laboratory, Glenn Research Center, Cleveland, Ohio 
The NASA STI Program Office ... in Profile

Since its founding, NASA has been dedicated to the advancement of aeronautics and space science. The NASA Scientific and Technical Information (STI) Program Office plays a key part in helping NASA maintain this important role.

The NASA STI Program Office is operated by Langley Research Center, the Lead Center for NASA's scientific and technical information. The NASA STI Program Office provides access to the NASA STI Database, the largest collection of aeronautical and space science STI in the world. The Program Office is also NASA's institutional mechanism for disseminating the results of its research and development activities. These results are published by NASA in the NASA STI Report Series, which includes the following report types:

- TECHNICAL PUBLICATION. Reports of completed research or a major significant phase of research that present the results of NASA programs and include extensive data or theoretical analysis. Includes compilations of significant scientific and technical data and information deemed to be of continuing reference value. NASA's counterpart of peerreviewed formal professional papers but has less stringent limitations on manuscript length and extent of graphic presentations.

- TECHNICAL MEMORANDUM. Scientific and technical findings that are preliminary or of specialized interest, e.g., quick release reports, working papers, and bibliographies that contain minimal annotation. Does not contain extensive analysis.

- CONTRACTOR REPORT. Scientific and technical findings by NASA-sponsored contractors and grantees.
- CONFERENCE PUBLICATION. Collected papers from scientific and technical conferences, symposia, seminars, or other meetings sponsored or cosponsored by NASA.

- SPECIAL PUBLICATION. Scientific, technical, or historical information from NASA programs, projects, and missions, often concerned with subjects having substantial public interest.

- TECHNICAL TRANSLATION. Englishlanguage translations of foreign scientific and technical material pertinent to NASA's mission.

Specialized services that complement the STI Program Office's diverse offerings include creating custom thesauri, building customized databases, organizing and publishing research results ... even providing videos.

For more information about the NASA STI Program Office, see the following:

- Access the NASA STI Program Home Page at http://www.sti.nasa.gov

- E-mail your question via the Internet to help@sti.nasa.gov

- Fax your question to the NASA Access Help Desk at 301-621-0134

- Telephone the NASA Access Help Desk at 301-621-0390

- Write to: NASA Access Help Desk NASA Center for AeroSpace Information 7121 Standard Drive Hanover, MD 21076 
NASA/TM-2002-211482
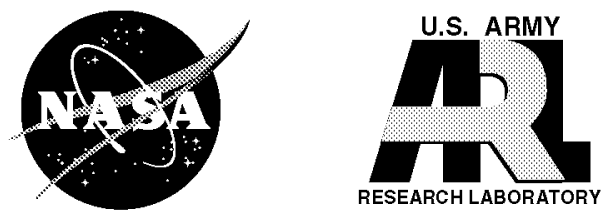

\section{A Systems Approach to the Solid Lubrication of Foil Air Bearings for Oil-Free Turbomachinery}

Christopher DellaCorte and Antonio R. Zaldana

Glenn Research Center, Cleveland, Ohio

Kevin C. Radil

U.S. Army Research Laboratory, Glenn Research Center, Cleveland, Ohio

National Aeronautics and

Space Administration

Glenn Research Center 
This report contains preliminary findings, subject to revision as analysis proceeds.

The Aerospace Propulsion and Power Program at NASA Glenn Research Center sponsored this work.

Trade names or manufacturers' names are used in this report for identification only. This usage does not constitute an official endorsement, either expressed or implied, by the National Aeronautics and Space Administration.

Available from

NASA Center for Aerospace Information 7121 Standard Drive

Hanover, MD 21076
National Technical Information Service 5285 Port Royal Road Springfield, VA 22100

Available electronically at http://gltrs.grc.nasa.gov 


\title{
A Systems Approach to the Solid Lubrication of Foil Air Bearings for Oil-Free Turbomachinery
}

\author{
Christopher DellaCorte and Antonio R. Zaldana \\ National Aeronautics and Space Administration \\ Glenn Research Center \\ Cleveland, Ohio 44135 \\ Kevin C. Radil \\ U.S. Army Research Laboratory \\ Glenn Research Center \\ Cleveland, Ohio 44135
}

\begin{abstract}
Foil air bearings are self-acting hydrodynamic bearings which rely upon solid lubricants to reduce friction and minimize wear during sliding which occurs at start-up and shut-down when surface speeds are too low to allow the formation of a hydrodynamic air film. This solid lubrication is typically accomplished by coating the non-moving foil surface with a thin, soft polymeric film. The following paper introduces a systems approach in which the solid lubrication is provided by a combination of self lubricating shaft coatings coupled with various wear resistant and lubricating foil coatings. The use of multiple materials, each providing different functions is modeled after oil-lubricated hydrodynamic sleeve bearing technology which utilizes various coatings and surface treatments in conjunction with oil lubricants to achieve optimum performance.

In this study, room temperature load capacity tests are performed on journal foil air bearings operating at 14,000 rpm. Different shaft and foil coating technologies such as plasma sprayed composites, ceramic, polymer and inorganic lubricant coatings are evaluated as foil bearing lubricants. The results indicate that bearing performance is improved through the individual use of the lubricants and treatments tested. Further, combining several solid lubricants together yielded synergistically better results than any material alone.
\end{abstract}

\section{Introduction}

Blok and Van Rossum published the first paper on foil bearings in 1953 (ref. 1). Although they coined the term "foil bearing," their work actually concerned an oil lubricated shaft running against an acetate film or "foil." The concept of a flexible bearing surface and its implications to and potential for improved capabilities was quickly adapted by other technologists and papers on air lubricated foil bearings began to appear in the open literature in the following decade (refs. 2 and 3).

Foil air bearings are similar to conventional oil-lubricated bearings in that the fluid film pressure is developed via the hydrodynamic effect. Unlike conventional bearings, foil air bearings use air as their working fluid and the bearing surface is compliant rather than rigid. This compliant inner or top foil surface is supported by a spring pack or bump foil layer which allows the bearing to accommodate shaft misalignment, thermal and centrifugal distortion, the presence of wear debris and also allows the designer to tailor the operational foil shape to enhance film pressure and hence bearing load capacity (ref. 4). Figure 1 schematically shows typical foil bearing designs. Micro-sliding, which occurs between the top foil and its spring support and within the spring foils, contributes significant coulomb damping properties 
to the bearing (ref. 5). Since foil bearings do not use oil as their working fluid they can and are routinely used over an extremely wide temperature range, from cryogenic to over $650^{\circ} \mathrm{C}$, not possible with oil lubrication.

Foil air bearings, however, do require solid lubrication to prevent wear and reduce friction at very low speeds encountered during start-up and shut-down prior to the development of the hydrodynamic gas film and also during momentary bearing overloads such as high speed rubs (ref. 6). Traditionally, this solid lubrication is provided by applying a thin polymer film or coating to the foil surface. This approach works well unless the coating wears through resulting in high friction and wear. Also, traditional solid lubricants (graphite, PTFE, $\mathrm{MoS}_{2}$ ), are temperature limited to only about $300^{\circ} \mathrm{C}$ (ref. 7). For higher temperatures and longer life alternate approaches must be considered.

One approach undertaken at the authors' laboratory is to coat the rotating shaft surface with a high temperature solid lubricant composite coating (ref. 8). This technique overcomes the problem of localized lubricant coating failure on a foil causing excessive friction and wear. When the shaft is coated, the rubbing surface of the foil is continually exposed to the entire shaft surface thereby reducing local wear spots that would form at highly loaded regions on the foil. By using the shaft coating as a reservoir for lubricants, a lubricious transfer film can form on the foil surface, in-situ, further improving tribological properties. One example of this approach is the PS304 coating. Reported on extensively in the literature, PS304 is a plasma sprayed composite coating made from a powder blend of $60 \mathrm{wt} \% \mathrm{NiCr}, 20 \mathrm{wt} \% \mathrm{Cr}_{2} \mathrm{O}_{3}$, $10 \mathrm{wt} \% \mathrm{Ag}$, and $10 \mathrm{wt} \% \mathrm{BaF}_{2} / \mathrm{CaF}_{2}$ eutectic (refs. 9 to 11). Each constituent in PS034 performs a unique function. The NiCr acts as a ductile matrix or binder, the chrome oxide as a wear resistant hardener and the silver and eutectic serve as low and high temperature solid lubricants respectively.

When applied to the shaft surface of a foil bearing system and subjected to repeated start/stop cycles, the solid lubricants form a soft surface layer, which also transfers to the foil surface. During high temperature operation, metal oxides from the superalloy foil and the $\mathrm{NiCr}$ binder phase in the PS304 coating also contribute to the formation of complex, glassy, lubricious surface films, which provide solid lubrication. Reference 11 reports on post test surface analyses of PS304 lubricated foil bearings run at discrete temperatures from 25 to $650^{\circ} \mathrm{C}$. At different operating temperatures surface films with different chemical compositions develop on the shaft and foil surfaces. Although their chemistry differs, these films all provide the same type of solid lubrication effect. In fact, PS304 lubricated bearings have demonstrated lives well in excess of 100000 start/stop cycles; greatly exceeding the requirements of all foreseen applications (ref. 12).

The successful demonstration of long lived, high temperature foil air bearings has prompted the initiation of research efforts to extend the application of foil air bearings to larger oil-free turbomachinery systems. Foil air bearings operating at low temperatures utilizing polymer foil coatings have been in commercial service in air cycle machines for aircraft cabin pressurization and cooling for over three decades (refs. 3 and 13). In these applications the oil-free, maintenance free characteristics offered by foil bearings is responsible for observed mean time between failures (MTBF's) of over 100000 hours. Low cost and quiet operation without the possibility of oil contamination of cabin air have made foil bearings the preferred shaft support technology in these machines. More recently, small oil-free microturbine electrical generators have been commercialized using foil bearings. Again, polymer or other thin film coatings form the basis for the solid lubrication of the bearings. As in the air cycle machine application, the primary benefit of oil-free technology is the long life and maintenance free characteristics of the bearings.

The first commercially available oil-free microturbine to be marketed produces $30 \mathrm{~kW}$ of electrical power at an engine speed of $96000 \mathrm{rpm}$ (ref. 14). This was followed shortly thereafter by a competitor with a $75 \mathrm{~kW}$ system using a larger engine rotating at somewhat lower speeds. More recently, several other companies are testing even larger prototype units with power output levels exceeding $200 \mathrm{~kW}$. Based upon these activities and additional technological developments there is a renewed interest in developing oil-free gas turbine aircraft engines utilizing advanced high temperature foil bearings and solid lubricants like PS304. To support the continuing development of oil-free aircraft engines, research 
is being conducted on bearing design and development, rotordynamic system modeling and solid lubrication. This paper describes an effort to further improve the solid lubrication performance of foil bearings operating against PS304 coated shafts.

Radil recently published a paper that shows that PS304 lubricated foil air bearings exhibit significantly reduced load capacities in their "as-installed" condition prior to being subjected to a break-in procedure of repeated high temperature start-stop cycles (ref. 16). He found that unworn, as-installed bearings had relatively rough shaft and foil surfaces that had not yet developed beneficial, lubricant rich surface transfer layers that form as the result of the low speed sliding which occurs during repeated start/stop cycling. Without the presence of polished surfaces and low friction surface films, high starting torque and reduced load capacity resulted. His work showed that improving the tribological properties, namely the smoothness and/or solid lubricating qualities, dramatically enhanced bearing load capacity.

Foil bearing load capacity is expressed in relation to a bearing's load capacity coefficient, $D$. This coefficient, defined fully in reference 17 , is an empirically established performance parameter which relates bearing size and speed to the load that a bearing can support. Mathematically, it is defined as follows:

$$
W=D(L \times d)(d \times \mathrm{Krpm})
$$

where:

$W$ is the maximum steady load that can be supported, $\mathrm{N}$ (lbs)

$D$ is the bearing load capacity coefficient, N/mm $3 \times \mathrm{Krpm}(\mathrm{lbs} / \mathrm{in} .3 \times \mathrm{Krpm})$

$L$ is the bearing axial length, $\mathrm{mm}$ (in.)

$d$ is the shaft diameter, $\mathrm{mm}$ (in.)

$\mathrm{Krpm}$ is the shaft rotational speed in thousands of revolutions per minute (Krpm)

This relationship can be remembered easily for advanced technology bearings, which have performance coefficients of around 1.0 when non-SI or English units are used. An advanced design (designated Generation III in ref. 17) foil bearing, like the type depicted in figure 2, will support about "one pound of load per in. ${ }^{2}$ of projected bearing area per inch of bearing diameter per thousand rpm." The earliest foil bearing designs, designated Generation I, had very simple elastic support structures (spring systems) and exhibited load capacity coefficients of around 0.3 . The development of more complex bearing designs in which the elastic foundation varied circumferentially or axially are defined as Generation II and exhibit load capacity coefficients around 0.5 . The most recent bearing designs have elastic structures which tailor the spring foundation both circumferentially and axially, are designated Generation III bearings, and have load capacity coefficients of about 1.0. Foil bearings used in air cycle machines are Generation I bearings. Generation II bearings have been used successfully in turbocompressors and small microturbines. It is expected that Generation III bearings with load capacity coefficients near 1.0 will be required for aircraft engine applications.

The Generation III bearings lubricated with PS304 shaft coatings produce load capacity coefficients of 0.9 to 1.0 from 25 to $650^{\circ} \mathrm{C}$ after they have been broken-in over repeated start/stop cycles at elevated temperatures (ref. 12). When the load capacity coefficient was measured for these same bearings in the as-installed condition the load capacity coefficient, $D$, at $25^{\circ} \mathrm{C}$ was only 0.3 , a three fold reduction (ref. 16). When a new foil bearing was fitted to a broken-in, PS304 coated shaft, the load capacity coefficient, $D$, rose to about 0.5 . Similarly, if a previously broken-in foil bearing was fitted to a newly ground PS304 coated shaft the coefficient was 0.6. Clearly, improving the tribological properties of each surface improves bearing performance, and improving both mating surfaces offers further improvements.

Theoretically, the load capacity of a foil air bearing is governed by its design, operating condition (speed and temperature) and the foil and shaft surface roughness. Load capacity is reached when the hydrodynamic gas film pressure forces no longer creates a gas film thickness greater than the sum of the average surface roughness of the foil and shaft. Higher loads, or lower speeds, reduces the air film thickness allowing rubbing contact between asperities (high points) of the foil and shaft surfaces leading to high friction, wear, thermal distortion and possibly seizure or friction welding. However, experimental 
research in which electrical continuity across the air film of a bearing was measured has shown that sporadic, localized rubbing contact can and does occur in running foil bearings even under low loads well below predicted load capacity (ref. 16). This contact may be the result of unexpected foil motions, fluttering for example, misalignment induced edge loading or entrapped debris. Whatever the reason(s), rubbing does occur and if a satisfactory solid lubricant is not present, galling and seizure can occur.

To achieve the maximum possible foil bearing load capacity a smooth surface finish, proper bearing design and adequate solid lubrication must be available at all times under all operating conditions. For bearings using PS304 shaft coatings, these conditions are achieved by breaking in the bearing surfaces over repeated start/stop operation at high temperatures. During this break-in period, the foil surface polishes the coating surface and a solid lubricant rich transfer film develops on both the foil and shaft resulting in a bearing with higher load capacity $(D \sim 1.0)$.

Unfortunately, in many real applications the opportunity for a prolonged, lightly loaded, high temperature break-in period does not exist. In applications like gas turbine engines, maximum bearing performance is required upon first starting the engine. Previous efforts by Blanchet and his colleagues to precondition bearing surfaces using bench level processes were shown to be ineffective (ref. 18). A practical method is needed to assure adequate foil bearing performance in an application from initial installation through final use.

The following research effort concentrates on identifying and developing a suitable solid lubrication method or system. The approach used includes, temporary, sacrificial coatings overlaid on the PS304 shaft coating; the use of thin, non-galling, wear resistant ceramic and metal films applied to foils; and various combinations of these tribological technologies. To test these concepts, Generation III foil bearings are operated at temperatures from 25 to $650{ }^{\circ} \mathrm{C}$, at $14000 \mathrm{rpm}$ under loads of 10 to $200 \mathrm{~N}$ as described in the following sections.

\section{Test Procedures and Materials}

\section{Baseline Bearing}

The foil air bearings used in this study are classified as Generation III, advanced technology bearings originally developed for an oil-free turbocharger. Their performance coefficient, $D$, after break-in using PS304 shaft coatings has been found to be around 1.0 from 25 to $650{ }^{\circ} \mathrm{C}$ (ref. 19). Their geometry is described in the patent literature (ref. 20). The extensive database available for this bearing design and size ( 26 by $35 \mathrm{~mm}$ ) provides a convenient baseline against which to judge newly developed solid lubrication methods and materials. The bearing foils are made from Inconel X-750 sheet metal with a typical surface finish of 0.1 microns Ra ( 4 micro in.). Prior to use, the bearings are cleaned in an ultrasonic bath of ethyl alcohol and dried using clean compressed air.

\section{PS304 Baseline Shaft Coating}

The shafts are $35 \mathrm{~mm}$ in diameter and are plasma spray coated with a $0.35 \mathrm{~mm}$ thick layer of PS304 which is then heat treated in air at $650{ }^{\circ} \mathrm{C}$ for $24 \mathrm{hr}$. This heat treatment strengthens the coating and assures dimensional stability (ref. 21). Following the heat treatment, the shafts are mounted on the test rig spindle, shown in figure 2 and fully described in reference 8 . After mounting, an in-place grinding system is used to achieve a coating thickness of about $0.25 \mathrm{~mm}$ and a surface finish of about 0.4 microns Ra. To improve this finish, the shaft is polished using silicon carbide abrasive paper with water as the polishing coolant. PS304 coated shafts prepared in this manner have surface roughness (Ra) of about 0.2 microns. Further polishing does not result in a smoother surface because of the porous nature of the plasma sprayed coating. 


\section{Foil Coatings}

Heat cured polyimide, cathodic arc deposited aluminum bronze $(\mathrm{Al}-\mathrm{Cu})$ and sputtered alumina $\left(\mathrm{Al}_{2} \mathrm{O}_{3}\right)$ were applied to foil surfaces to improve friction and wear properties. The polyimide, described fully in reference 22, is applied using an air spray gun, air dried at room temperature and then oven cured at $200{ }^{\circ} \mathrm{C}$. Several coating applications are used with burnishing (light sanding) between layers to build up a final coating of about $0.1 \mathrm{~mm}$ thickness. The polyimide is commercially available and provides low wear and friction in sliding and is capable of operating in air to about $300^{\circ} \mathrm{C}$. At higher temperatures, the polyimide oxidizes readily and burns away.

The Al-Cu coating was applied in a vacuum chamber using a physical vapor deposition process, which results in a hard rough coating deposit about $0.2 \mathrm{~mm}$ thick. This coating is polished smooth using silicon carbide sandpaper ( 600 grit) with water resulting in a surface finish of about 0.1 microns Ra. The Al-Cu coating contains about 4 percent aluminum is sometimes referred to as aluminum bronze and is used as a common high temperature anti-fretting coating for gas turbines. It oxidizes readily in air above $400{ }^{\circ} \mathrm{C}$ forming a soft, lubricious copper oxide patina.

The Alumina, $\mathrm{Al}_{2} \mathrm{O}_{3}$, is also deposited in a vacuum chamber using a sputtering process described in detail in reference 23 . The resulting surface finish matches that of the underlying foil and requires no post deposition polishing. Alumina is not considered a solid lubricant. Rather, it is a non-galling, wear resistant coating which has been shown to work well in contact with PS304 in earlier tests (ref. 24).

\section{Solid Lubricant Overlay Coatings}

Fully prepared (sprayed, heat treated, ground, and polished) PS304 shaft coatings were overcoated with either the polyimide, described in the previous section or Molybdenum Disulphide $\left(\mathrm{MoS}_{2}\right)$ for additional solid lubrication. Neither the polyimide nor $\mathrm{MoS}_{2}$ is a high temperature lubricant. Rather, they are selected as sacrificial solid lubricants, intended to provide low friction during initial low temperature operation. At high temperatures it is expected that these will oxidize and then volitalize (burn away). It is hoped that by the time these overlay solid lubricants burn away, the break-in process of the underlying PS304 coating will be complete and provide acceptable bearing load capacity performance.

The polyimide is deposited onto the PS304 surface in three layers as is done on the foils and burnished to a thickness of about $0.05 \mathrm{~mm}$. Several specimens were also prepared with thinner coatings by increasing the amount of reducer used in the mixing of the polyimide prior to spray application. These films were burnished to a thickness of only $0.02 \mathrm{~mm}$. One benefit of using overlay coatings on the PS304 is that the overlay coatings fill in the surface pits in the PS304 resulting in much smoother shaft surfaces, typically 0.1 micron Ra.

The $\mathrm{MoS}_{2}$ is also sprayed onto the prepared PS304 surface using an aerosol propellant in an isopropyl alcohol vehicle. This colloidal form of $\mathrm{MoS}_{2}$ is readily available in aerosol cans from number of manufacturers (ref. 25). Following deposition, the coating rapidly air dries at room temperature and is polished using a soft cloth to a mirror like finish with a roughness of about 0.05 micron Ra. The polished coating is about 0.05 micron thick.

\section{Testing}

A foil bearing load capacity test designed to simulate the conditions that may be encountered in an oil-free aircraft engine bearing was developed to evaluate the solid lubrication materials and methods selected in this work. Namely, upon installation in the test rig the bearings were tested for load capacity at room temperature to simulate a cold engine start. This is followed by testing at $14000 \mathrm{rpm}$ constant speed under about a $75 \mathrm{~N}$ load and increasing the temperature in approximately $100^{\circ} \mathrm{C}$ increments to $650^{\circ} \mathrm{C}$.

The bearings were held at each test temperature for at least ten minutes to assure that thermal stability had 
been achieved. Lift off was confirmed by a low and steady torque trace measured using a load cell mounted outside the furnace chamber. Load capacity at each test temperature was verified by increasing the load in $10 \mathrm{~N}$ increments until a rapid rise in friction (torque) signaled that the bearing load capacity had been reached. Additionally, following the high temperature tests, the load capacity was then measured at room temperature to determine if the bearing performance was changed by the high temperature operation. This simulates, for example, the second and subsequent flights of an aircraft engine. Additionally, selected bearings were tested in a start/stop cycling mode during heating from 25 to $650{ }^{\circ} \mathrm{C}$ to determine if solid lubricants provided satisfactory performance during pure sliding over the entire operating temperature range.

\section{Results and Discussion}

The test results are summarized in Table II. This table incorporates the data collected in the present study as well as comparable data published previously. The data source is clearly marked in the table. The results corroborate earlier work in that the best bearing performance (load capacity coefficient) is achieved when the foil and the shaft surface have good solid film lubrication characteristics, either by transfer film formation or intentionally applied solid lubricant coatings and when both surfaces are smooth and conform to one another (i.e., are broken in together). To better elucidate this finding, the data is grouped by level of tribological complexity starting with the simplest case of PS304 running against an uncoated foil, the baseline case and leading to results from bearings provided with additional lubrication by shaft overlay and foil coatings.

\section{PS304 Coated Shaft Running Against Uncoated Foil}

This baseline case combination yields a load capacity coefficient at room temperature of only 0.3 in the as installed condition. Following sustained operation with a constant load at high temperature does not result in significant improvements in the coefficient measured after cooling to $25^{\circ} \mathrm{C}$. During high temperature operation the load capacity coefficient was slightly higher, about 0.5 , as the result of the formation of surface oxides on the foil and the PS304 but nowhere near the performance coefficients of 1.0 achieved following start/stop break-in. It is this loss of half of the bearing load capacity that the current research is trying to regain through the use of additional coatings and treatments.

\section{PS304 Coated Shaft Running Against $\mathrm{Al}_{2} \mathrm{O}_{3}$ or $\mathrm{Al}-\mathrm{Cu}$ Coated Foil}

The use of both of these wear resistant, non-galling foil coatings improved the load capacity performance of the foil bearings. The load capacity coefficient for the Al-Cu was 0.5 and for the $\mathrm{Al}_{2} \mathrm{O}_{3}$ was 0.47 running against PS304 in the as-installed condition. When tested against a previously broken-in PS304 coated shaft the coefficient for the Al-Cu rose to 0.7 and the coefficient for Al2O3 rose only to 0.56 about the same as for a newly installed bare foil bearing running against previously broken-in PS304. These results are shown in figure 4 . While both coatings offered improvements in the as installed condition, the Al-Cu gave better performance.

\section{Polyimide and $\mathrm{MoS}_{2}$ Overlay Shaft Coatings and Polyimide Foil Coatings}

The results clearly show the beneficial effects of the use of traditional solid lubricants on foil bearing load capacity. Polyimide applied to either the foil or the PS304 coated shaft and $\mathrm{MoS}_{2}$ deposited over the PS304 dramatically improved the room temperature, as installed load capacities. Polyimide coated foils 
had a coefficient of 0.73 when tested against the prepared PS304 surface. This is lower than for a fully broken in PS304/uncoated foil case $(D \sim 1.0)$ but over twice the coefficient for the same test without the polyimide $(D \sim 0.3)$. When the polyimide was applied to the PS304 surface as an overlay the coefficient rose to 1.25 when tested against a new uncoated foil bearing. This result confirms the earlier assertion that providing lubrication to the bearing via a shaft coating is better than relying on foil coatings. For the $\mathrm{MoS}_{2}$ overcoated PS304 running against an uncoated foil the coefficient was 0.89 at room temperature. This value is about equal to a fully broken in baseline bearing.

The true value of these overlay coatings cannot be known until their characteristics are observed during and following use at high temperatures. $\mathrm{MoS}_{2}$ and the polyimide are low temperature lubricants only intended for temporary use. At high temperatures they will oxidize and lose their lubricating ability. When this occurs it is expected that the lubricating properties of the other coatings, namely the PS304, will develop and provide adequate solid lubrication in the form of surface layers and transfer films. To make this transition possible, the overlay coatings must decompose in a benign manner. To test this concept, burn-off tests were conducted in which either the bearing was run at a constant speed under a steady load (corresponding to a $D \sim 0.5$ ) or run in a cyclic or start/stop mode under a light static load $(D \sim 0.1)$ while the test temperature was increased from 25 to $650^{\circ} \mathrm{C}$. Both $\mathrm{MoS}_{2}$ and the polyimide lose their effectiveness above $300{ }^{\circ} \mathrm{C}$, oxidize and then vaporize above $500{ }^{\circ} \mathrm{C}$. Bearing torque is monitored during these burn-off tests as a general indicator of performance.

The polyimide coated bearings repeatedly failed during both the continuous, moderate load burn-off tests and during the cyclic, light load burn-off tests. At about $350^{\circ} \mathrm{C}$, the bearing torque began to increase. At temperatures between 400 and $537^{\circ} \mathrm{C}$, all of the test bearings seized. Upon disassembly and visual inspection, it was observed that the bearings were jammed with large ( 100 micron), hard particles formed during the thermal decomposition of the polyimide. SEM analyses failed to determine the exact chemical nature of this debris, however, the presence of silicon was noted suggesting, perhaps, the formation of a glass-like particle. The polyimide is a commercial product and it has been known that glass particle additives are sometimes used to control coating texture and hardness (ref. 22). Only one polyimide coated bearing did not fail catastrophically. This bearing had most of the polyimide film removed by polishing prior to the burn-off test and was run continuously under a very light $(D \sim 0.2)$ load. Though torque rose during the burn-off seizure did not occur. Clearly, in foil bearings the polyimide does not degrade in a benign fashion.

The results with $\mathrm{MoS}_{2}$ were much more encouraging. Applying an $\mathrm{MoS}_{2}$ overlay to the prepared PS304 surface run against an uncoated Inconel foil yielded a performance coefficient of 0.89 . This value is approximately the same as a fully broken in PS304/uncoated foil combination. During a continuous speed burn-off test under moderate load, no bearing torque changes or failure (seizure) occurred. Following this successful burn-off test, the bearing was cooled to room temperature and the load capacity coefficient was found to be 0.54 . This is lower than the previous value of 0.89 but higher than the value for the baseline as-installed PS304/uncoated foil without start/stop break-in of 0.3. When this same combination, PS304 $+\mathrm{MoS}_{2} /$ uncoated foil, was subjected to a burn-off test under start/stop cycles no failure occurred and the measured coefficient after cooling to $25^{\circ} \mathrm{C}$ was 0.89 . Clearly, the $\mathrm{MoS}_{2}$ overlay improves initial performance but does not adversely affect long term bearing operation.

\section{Combined Wear Resistant Foil Coating and Sacrificial Overlay Coatings}

The overall load capacity performance is significantly improved under all conditions by the use of sacrificial overlay solid lubricants coupled with PS304 shaft coatings and non-galling, wear resistant foil coatings like Al-Cu. For instance, when $\mathrm{MoS}_{2}$ was applied on prepared PS304 and run against an unworn $\mathrm{Al}-\mathrm{Cu}$ coated foil bearing at $25^{\circ} \mathrm{C}$ the load capacity coefficient was 1.0 . This is 10 percent higher than the same shaft against a bare foil and 30 percent higher than an Al-Cu coated foil against a broken-in PS304 shaft and twice as high as the same Al-Cu coated foil running against an as prepared PS304 shaft without an $\mathrm{MoS}_{2}$ overlay coating. Further, this apparent synergistic solid lubricant effect continues even after the 
burn-off tests. The data in Table II clearly shows that the bearing coefficients using both the $\mathrm{MoS}_{2}$ overlay, PS304 shaft coatings and Al-Cu foil coatings were between 0.9 and 1.0 under all conditions tested. This performance is better than any other solid lubricant method (coating) by itself. These results are graphically portrayed in figure 4.

The purpose of this research effort is to overcome the diminished load capacity observed for unworn, newly installed foil bearings which use PS304 shaft coatings. Nearly all performance data published to date, with the exception of reference 16, gives foil bearing load capacity for bearings fully broken in during elevated temperature start/stop cycles. Under these conditions, the PS304 and the counterface foil surfaces self polish and develop smooth solid lubricant rich layers, which dramatically improve the load carrying capability of the bearings. Blanchet and his co-workers have attempted to develop techniques to achieve smoother surface finishes of PS304 and pre-develop lubricious surface layers but have been largely unsuccessful. Their work concentrated on surface polishing and pre-wearing the PS304 shaft coating against Inconel surfaces prior to testing. The approach taken here is different and upon further reflection is very similar to that taken in ordinary oil-lubricated sleeve bearings used, for instance, in crankshaft bearings in automobile engines.

The hydrodynamic, oil-lubricated journal bearings found in internal combustion piston engines utilize a complex tribological system for successful operation. This system incorporates careful, detailed geometrical design to optimize the formation of the lubricating fluid film. The geometry of the bearing is coupled with materials design embodied by a series of layers on the bearing surfaces to provide enhanced performance when the oil film is insufficient to adequately separate the two surfaces. For instance, the bearing shells are made from steel, which is then copper coated to improve heat transfer and fatigue resistance. This copper layer is then coated with a soft metal (babbit) overlay to minimize scratching of the shaft during starts and stops and to allow imbedding of hard debris particles that might otherwise scuff the shaft and bearings. The shafts too are often treated to increase their surface hardness, either by chrome plating, hard carburizing or other heat treatments. This complex lubrication system has been developed over many decades and allows brand new bearings to operate at acceptable performance levels even before their break-in procedure has been completed. Further, the system of lubricants and coatings provides additional protection to the bearing to compensate for environmental conditions which exceed nominal values such as momentary overloads, thermally induced misalignments, debris ingestion and geometrical changes due to wear.

By treating the foil air bearing in the same fashion, a tribological system can be developed to yield acceptable performance characteristics over the entire bearing life encompassing new installations and fully broken in bearings near the end of their useful life. Since most engineering applications of foil air bearings, gas turbines for example, require maximum load capacity from initial start-up it is crucial that a systems approach to bearing lubrication be employed. For instance, it would be impractical to operate an aircraft gas turbine at low power levels, over repeated start/stop cycles to allow gentle, gradual break-in of the bearings. Without a satisfactory tribological system such as that demonstrated in this paper, practical foil bearing use would be limited.

The data suggest that good performance is exhibited when wear resistant bearing surfaces are covered with thin, smooth solid lubricants. This condition exists for well broken-in PS304/uncoated Inconel foil bearings as well as newly installed PS304 overlaid with $\mathrm{MoS}_{2} / \mathrm{Al}-\mathrm{Cu}$ coated foil bearings. Further, since the use of alumina also improved the foil bearing load capacity it is likely that other materials, which provide similar tribological functionality, will work as well. Indeed, the polyimide worked well as a room temperature overlay coating and was only found unsuitable because it created large, hard debris during its thermal decomposition (burn-off). Figure 5 shows a schematic representation of the tribological "systems" used in both oil lubricated and air lubricated bearings. The use of a hydrodynamic fluid, wear resistant materials and solid lubricants are striking similarities.

Interestingly, early pioneering efforts in rigid gas bearings by S.F. Murray postulated a similar approach to solid lubrication (ref. 26). In his report, he pointed out that no matter how lightly loaded and well designed the air bearing was solid contact will occur due to misalignment, thermal and centrifugal effects, wear debris, overloads and other problems (bearing instabilities). He found that adequate solid 
lubrication must be employed to prevent damage. The same appears to be true for foil bearings. During start/stop or under heavy sustained loads occasional, localized sliding does occur and the tribological properties of the contacting surfaces have a dramatic effect on bearing load capacity performance.

\section{Concluding Remarks}

The results of this research clearly indicate that at least three conditions must be met to achieve good load capacity of foil air bearings; proper geometrical design, smooth surface finish and adequate solid lubrication and wear resistance. If any of these are not met bearing performance or life suffers. Early work utilizing PS304 as the sole source of solid lubrication yielded good results only after repeated high temperature start/stop operation encouraged the formation of smooth surfaces and lubricious transfer films on both the foils and the shaft. In order to achieve good performance upon initial installation it was shown that an effective solid lubricant film, such as $\mathrm{MoS}_{2}$, must be present on the shaft or foil. Non-galling wear resistant coatings such as PS304 on the shaft and Al-Cu on the foil enhances performance even more. To prevent bearing failure, the materials selected must not produce large hard debris particles as was the case for the polyimide, especially upon thermal decomposition (burn-off).

It appears that the combination of PS304 shaft coatings with a sacrificial layer of $\mathrm{MoS}_{2}$ running against Al-Cu coated foils works synergistically to give maximum load capacity from first installation to fully run-in foil bearing operation. These results are expected to be relevant to other highly loaded foil air bearing designs and geometries and solid lubricants. Based upon the findings presented, oil-free turbomachinery using foil bearings have promise as practical systems.

\section{References}

1. Blok, H.; and vanRossum, J.J.: The Foil Bearing-A New Departure in Hydrodynamic Lubrication. ASLE, Lubrication Engineering, pp. 316-330, December 1953.

2. Ma, J.T.S.: An Investigation of Self-Acting Foil Bearings. ASME, Journal of Basic Engineering, pp. 837-846, December 1965.

3. Barnett, M.A.; and Silver, A.: Application of Air Bearings to High Speed Turbomachinery. SAE Paper 700720, September 1970.

4. Gross, W.A.: Gas Film Lubrication, John Wiley and Sons, Inc., 1962.

5. Heshmat, H.; Shapiro, W.; and Gray, S.: Development of Foil Journal Bearings for High Load Capacity and High Speed Whirl Stability. ASME Journal of Lubrication Technology, vol. 104, no. 2, pp. 149-156, 1982.

6. DellaCorte, C.; and Wood, J.C.: High Temperature Solid Lubricant Materials for Heavy Duty and Advanced Heat Engines. NASA TM-106570, September 1994.

7. Wagner, R.C.; and Sliney, H.E.: Effects of Silver and Group II Fluorides Addition to Plasma Sprayed Chromium Carbide High Temperature Solid Lubricant for Foil Gas Bearings to $650{ }^{\circ} \mathrm{C}$. NASA TM-86895, 1985, ASLE, Lubrication Engineering (42), vol. 10, pp. 594-600, 1986.

8. DellaCorte, C.: Composition Optimization of $\mathrm{Cr}_{3} \mathrm{C}_{2}$ Based Solid Lubricant Coatings for Foil Gas Bearings at Temperatures to $650^{\circ} \mathrm{C}$. NASA CR-179649, July 1987.

9. DellaCorte, C.; and Edmonds, B.J.: Preliminary Evaluation of PS300: A Self-Lubricating High Temperature Composite Coating for Use to $800^{\circ} \mathrm{C}$. NASA TM-107056 (199).

10. DellaCorte, C.; and Fellenstein, J.A.: The Effects of Compositional Tailoring on the Thermal Expansion and Tribological Properties of PS300: A Solid Lubricant Composite Coating. NASA TM-107332, 1996.

11. DellaCorte, C.: The Evaluation of a Modified Chrome Oxide Based High Temperature Solid Lubricant Coating for Foil Gas Bearings. NASA/TM-1998-208660. 
12. DellaCorte, C.; Valco, M.J.; Radil, K.C.; and Heshmat, H.: Performance and Durability of High Temperature Foil Air Bearings for Oil-Free Turbomachinery. NASA/TM-2000-209187.

13. Emerson, T.P.: The Application of Foil Air Bearing Turbomachinery in Aircraft Environmental Control Systems. ASME Proceedings of the Intersociety Conference on Environmental Systems, San Diego, CA, July 10-13, 1978, Paper number 780-ENAS-18.

14. Capstone Microturbine Corporation, Chatsfield, CA, press release, 2000.

15. Heshmat, H.; Walton III, J.F.; DellaCorte, C.; and Valco, M.J.: Oil-Free Turbocharger Paves the Way to Gas Turbine Engine Applications. ASME 2000-GT-620, 2000.

16. Radil, K.C.; and DellaCorte, C.: The Effect of Journal Roughness and Foil Coatings on the Performance of Heavily Loaded Foil Air Bearings. NASA/TM-2000-210941.

17. DellaCorte, C.; and Valco, M.J.: Load Capacity Estimation of Foil Air Journal Bearings for Oil-Free Turbomachinery Applications. NASA/TM-2000-209782, and STLE Tribology Transactions, 43(1), October 2000.

18. Kim, Jong-Hwan: Surface Roughness, Tribology, Stress Analysis of Thermal-Sprayed Composite Coatings for Foil Gas Bearings. Ph.D. Dissertation, Rensselaer Polytechnic Institute, Troy, NY, October 2001.

19. DellaCorte, C.: A New Foil Air Bearing Test Rig for Use to $700{ }^{\circ} \mathrm{C}$ and $70,000 \mathrm{rpm}$. STLE Tribology Transactions, vol. 41, no. 3, 1998, pp. 335-340.

20. Heshmat, H.: High Load Capacity Journal Foil Bearing. U.S. Patent \#5,988,885, November 1999.

21. DellaCorte, C.; Edmonds, B.J.; and Benoy, P.A.: Thermal Processing Effects on the Adhesive Strength of PS304 High Temperature Solid Lubricant Coatings. NASA/TM-2001-210944.

22. Wagner, R.C.: Experimental Test Program for Evaluation of Solid Lubricant Coatings as Applied to Compliant Foil Gas Bearings to $315^{\circ} \mathrm{C}$. NASA CR-17483, 1985.

23. Lei, J.F.: Advances in Thin Film Sensor Technologies for Engine Applications. ASME 97-GT-458, ASME, NY (1997).

24. DellaCorte, C.; Fellenstein, J.A.; and Benoy, P.A.: Evaluation of Advanced Solid Lubricant Coatings for Foil Air Bearings Operating at 25 and $500{ }^{\circ} \mathrm{C}$. STLE Tribology Transactions, vol. 42, no. 2, pp. 338-342, April 1999.

25. Acheson Colloids Company, Port Huron, MI.

26. Murray, S.F.: Research and Development of High Temperature Gas Bearings. Volume II, NASA CR-MTI-TR-22, March 1969.

Table I.-Materials

\begin{tabular}{|l|l|l|}
\hline \multicolumn{1}{|c|}{ Component/Coating } & \multicolumn{1}{|c|}{ Composition/Characteristic } & \multicolumn{1}{c|}{ Function/Attributes } \\
\hline Foil material & Inconel X-750 & High temperature spring properties \\
\hline Shaft material & Inconel 718 & High temperature strength \\
\hline PS304 coating & $60 \mathrm{NiCr}, 20 \mathrm{Cr}_{2} \mathrm{O}_{3}, 10 \mathrm{Ag}, 10 \mathrm{BaF}_{2} / \mathrm{CaF}_{2}$ & Wear resistant solid lubricant \\
\hline Alumina coating & $\mathrm{Al}_{2} \mathrm{O}_{3}$ & Wear resistant sputtered film \\
\hline Aluminum bronze coating & $\mathrm{Al}-\mathrm{Cu}(4$ to 96 percent) & Wear resistant cathodic arc deposited \\
\hline Polyimide coating & Organic polymer & $\begin{array}{l}\text { Sacrificial solid lubricant air spray heat-cured } \\
\text { polymer coating }\end{array}$ \\
\hline $\mathrm{MoS}_{2}$ & $\mathrm{MoS}_{2}$ in an alcohol carrier & Sacrificial solid lubricant coating \\
\hline
\end{tabular}


Table II.-Data summary

\begin{tabular}{|c|c|c|c|c|}
\hline Shaft surface & Foil surface & Type of test & $\mathrm{D}$ & Data source/Comments \\
\hline PS304 as-prepared & Uncoated-unworn & $\begin{array}{l}\text { Load capacity, } \\
30 \mathrm{Krpm}\end{array}$ & 0.33 & $25^{\circ} \mathrm{C}$, as-installed load capacity (ref. 16) \\
\hline PS304 broken-in & Uncoated-unworn & $\begin{array}{l}\text { Load capacity, } \\
30 \mathrm{Krpm}\end{array}$ & 0.56 & $25^{\circ} \mathrm{C}$, new bearing, worn shaft (ref. 16) \\
\hline PS304 broken-in & Uncoated-broken-in & $\begin{array}{l}\text { Load capacity, } \\
30 \mathrm{Krpm}\end{array}$ & $\sim 1.0$ & $\begin{array}{l}25 \text { to } 650^{\circ} \mathrm{C} \text {, fully broken in bearing/ } \\
\text { shaft (ref. 19) }\end{array}$ \\
\hline PS304 as-prepared & $\mathrm{Al}_{2} \mathrm{O}_{3}$ unworn & $\begin{array}{l}\text { Load capacity, } \\
30 \mathrm{Krpm}\end{array}$ & 0.47 & $25^{\circ} \mathrm{C}$, as-installed load capacity (ref. 16 ) \\
\hline PS304 broken-in & $\mathrm{Al}_{2} \mathrm{O}_{3}$ unworn & $\begin{array}{l}\text { Load capacity, } \\
30 \mathrm{Krpm}\end{array}$ & 0.56 & $25^{\circ} \mathrm{C}$, new bearing, worn shaft (ref. 16) \\
\hline PS304 as-prepared & $\mathrm{AlCu}$ unworn & $\begin{array}{l}\text { Load capacity, } \\
30 \mathrm{Krpm}\end{array}$ & 0.50 & $25^{\circ} \mathrm{C}$, as-installed load capacity (ref. 16) \\
\hline PS304 broken-in & AlCu unworn & $\begin{array}{l}\text { Load capacity, } \\
30 \mathrm{Krpm}\end{array}$ & 0.70 & $25^{\circ} \mathrm{C}$, new bearing, worn shaft (ref. 16) \\
\hline PS304 as-prepared & Polyimide coated foil & $\begin{array}{l}\text { Load capacity, } \\
30 \mathrm{Krpm}\end{array}$ & 0.73 & $25^{\circ} \mathrm{C}$, as-installed load capacity (ref. 16) \\
\hline PS304 broken-in & Polyimide coated foil & $\begin{array}{l}\text { Load capacity, } \\
30 \mathrm{Krpm}\end{array}$ & 1.05 & $25^{\circ} \mathrm{C}$, new bearing, worn shaft, (ref. 16) \\
\hline PS304 polyimide coated & Uncoated-unworn & $\begin{array}{l}\text { Load capacity, } \\
14 \mathrm{Krpm}\end{array}$ & 1.25 & $25^{\circ} \mathrm{C}$, as-installed load capacity \\
\hline PS304 $\mathrm{MoS}_{2}$ coated & Uncoated-unworn & $\begin{array}{l}\text { Load capacity, } \\
14 \mathrm{Krpm}\end{array}$ & 0.89 & $25^{\circ} \mathrm{C}$, as-installed load capacity \\
\hline PS304 polyimide coated & Uncoated-unworn & $\begin{array}{l}\text { Burn-off/ } \\
\text { Constant speed }\end{array}$ & -- & Seizure above $400^{\circ} \mathrm{C}$ \\
\hline PS304 thin polyimide coated & Uncoated-unworn & $\begin{array}{l}\text { Burn-off/ } \\
\text { Constant speed }\end{array}$ & -- & Light load, torque rose but no seizure \\
\hline PS304 $\mathrm{MoS}_{2}$ coated & Uncoated-unworn & $\begin{array}{l}\text { Burn-off } / \\
\text { Constant speed }\end{array}$ & 0.54 & D measured at $25^{\circ} \mathrm{C}$ following burn-off \\
\hline PS304 $\mathrm{MoS}_{2}$ coated & Uncoated-unworn & $\begin{array}{l}\text { Burn-off/ } \\
\text { Start-stop }\end{array}$ & 0.89 & D measured at $25^{\circ} \mathrm{C}$ following burn-off \\
\hline PS304 $\mathrm{MoS}_{2}$ coated & $\mathrm{AlCu}$ unworn & $\begin{array}{l}\text { Load capacity, } \\
14 \mathrm{Krpm}\end{array}$ & 1.0 & $25^{\circ} \mathrm{C}$, as-installed load capacity \\
\hline PS304 $\mathrm{MoS}_{2}$ coated & AlCu unworn & $\begin{array}{l}\text { Burn-off/ } \\
\text { Constant speed }\end{array}$ & 0.9 & D measured at $25^{\circ} \mathrm{C}$ following burn-off \\
\hline PS304 MoS 2 coated & $\mathrm{AlCu}$ worn & $\begin{array}{l}\text { Burn-off/ } \\
\text { Start-stop }\end{array}$ & 1.0 & D measured at $25^{\circ} \mathrm{C}$ following burn-off \\
\hline PS304 $\mathrm{MoS}_{2}$ coated/worn & $\mathrm{AlCu}$ worn & $\begin{array}{l}\text { Extended burn- } \\
\text { off/Start-stop }\end{array}$ & 1.36 & $\begin{array}{l}\mathrm{D} \text { measured at } 25^{\circ} \mathrm{C} \text { following extended } \\
\text { start/stop }\end{array}$ \\
\hline PS304 $\mathrm{MoS}_{2}$ coated & $\mathrm{AlCu}$ worn & $\begin{array}{l}\text { Load capacity, } \\
14 \mathrm{Krpm}\end{array}$ & 1.05 & $\begin{array}{l}25^{\circ} \mathrm{C} \text {, preworn bearing, new shaft load } \\
\text { capacity }\end{array}$ \\
\hline
\end{tabular}



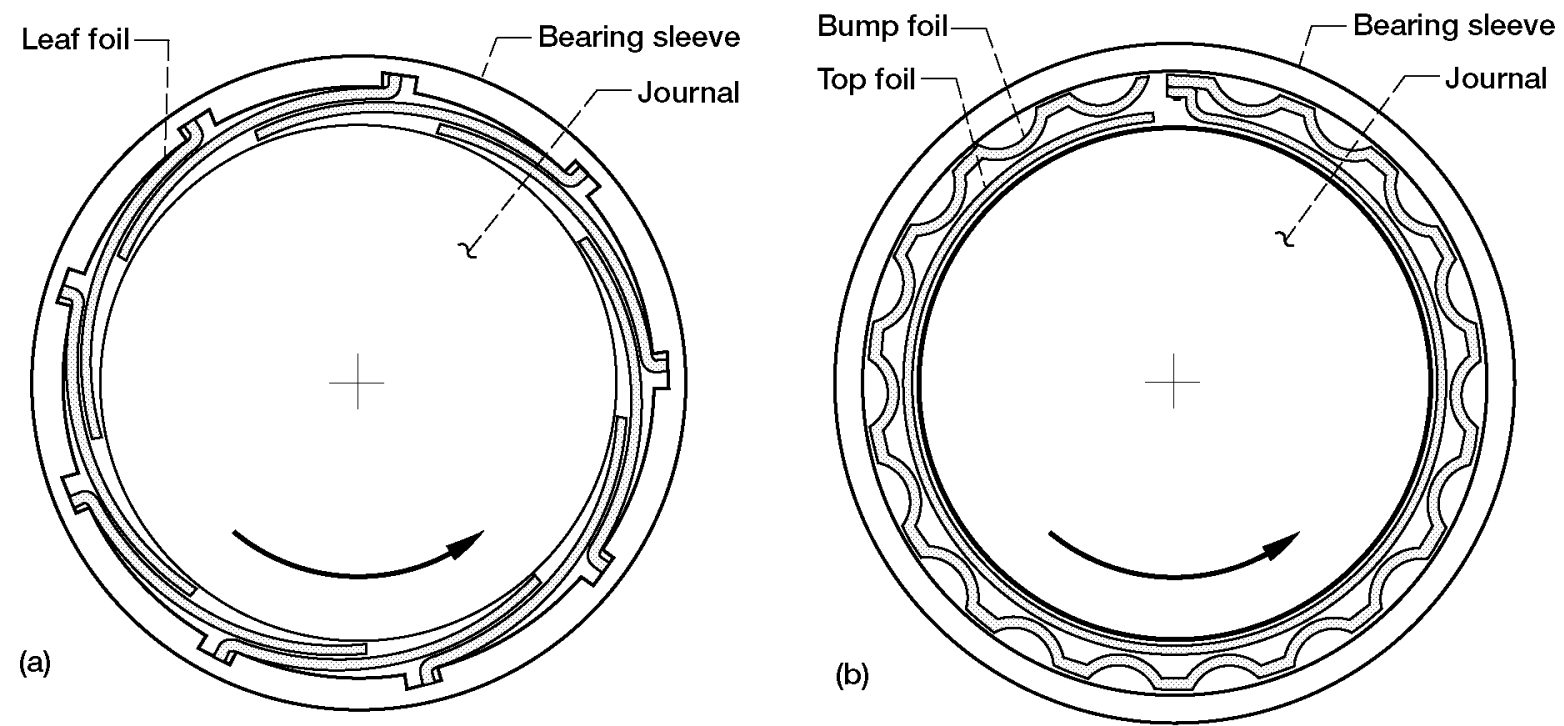

Figure 1.-Schematic example of typical first generation foil bearings with axially and circumferentially uniform elastic support elements. (a) Leaf-type foil bearing. (b) Bump-type foil bearing.

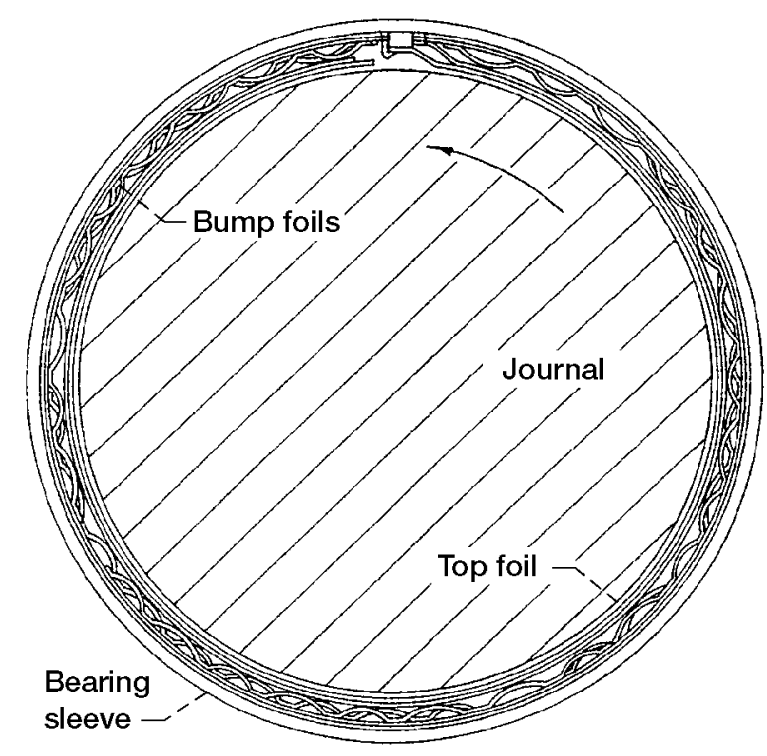

Figure 2.-Schematic of Generation III foil air bearing tested. 


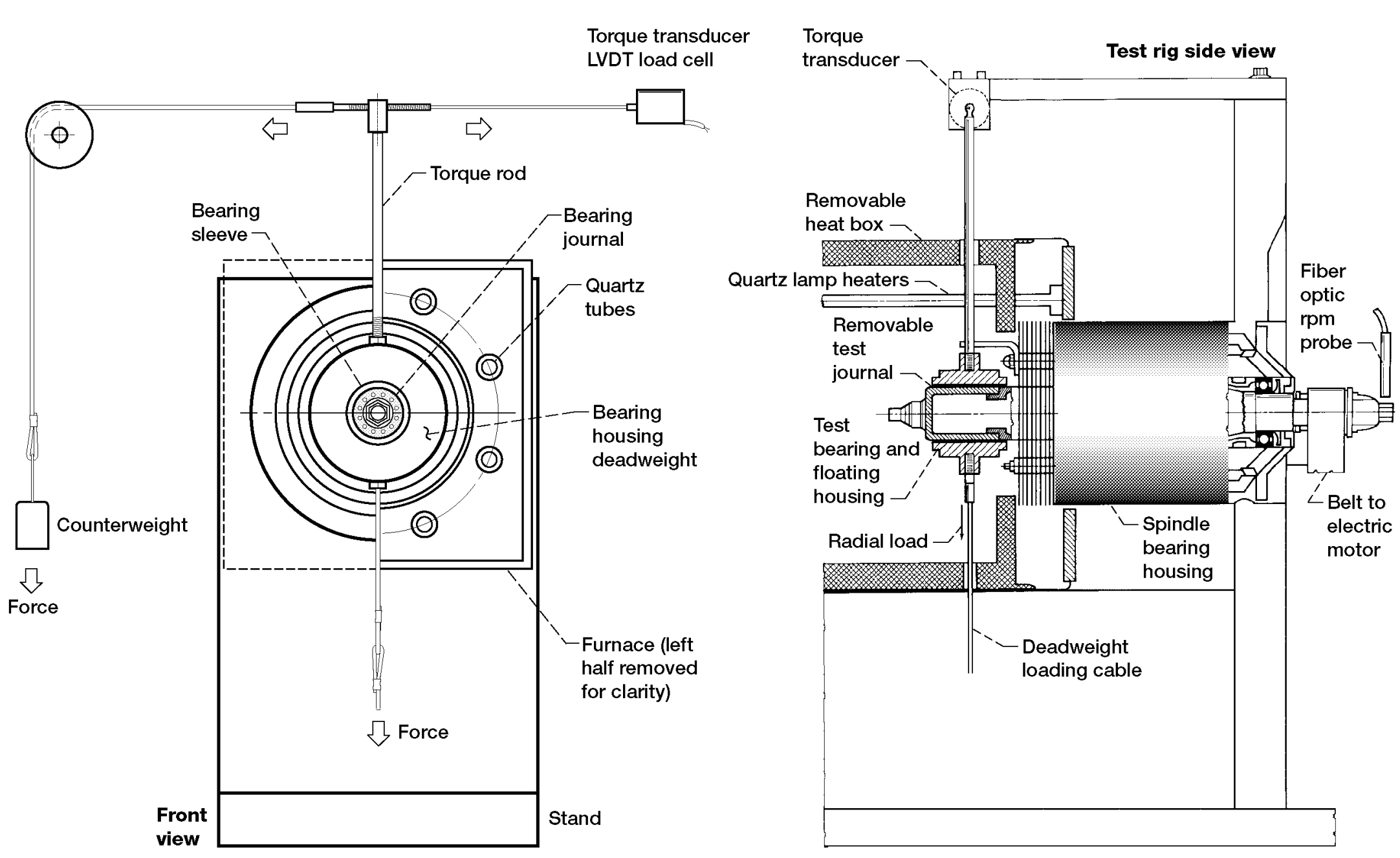

Figure 3.-Foil bearing test rig and bearing set-up. 


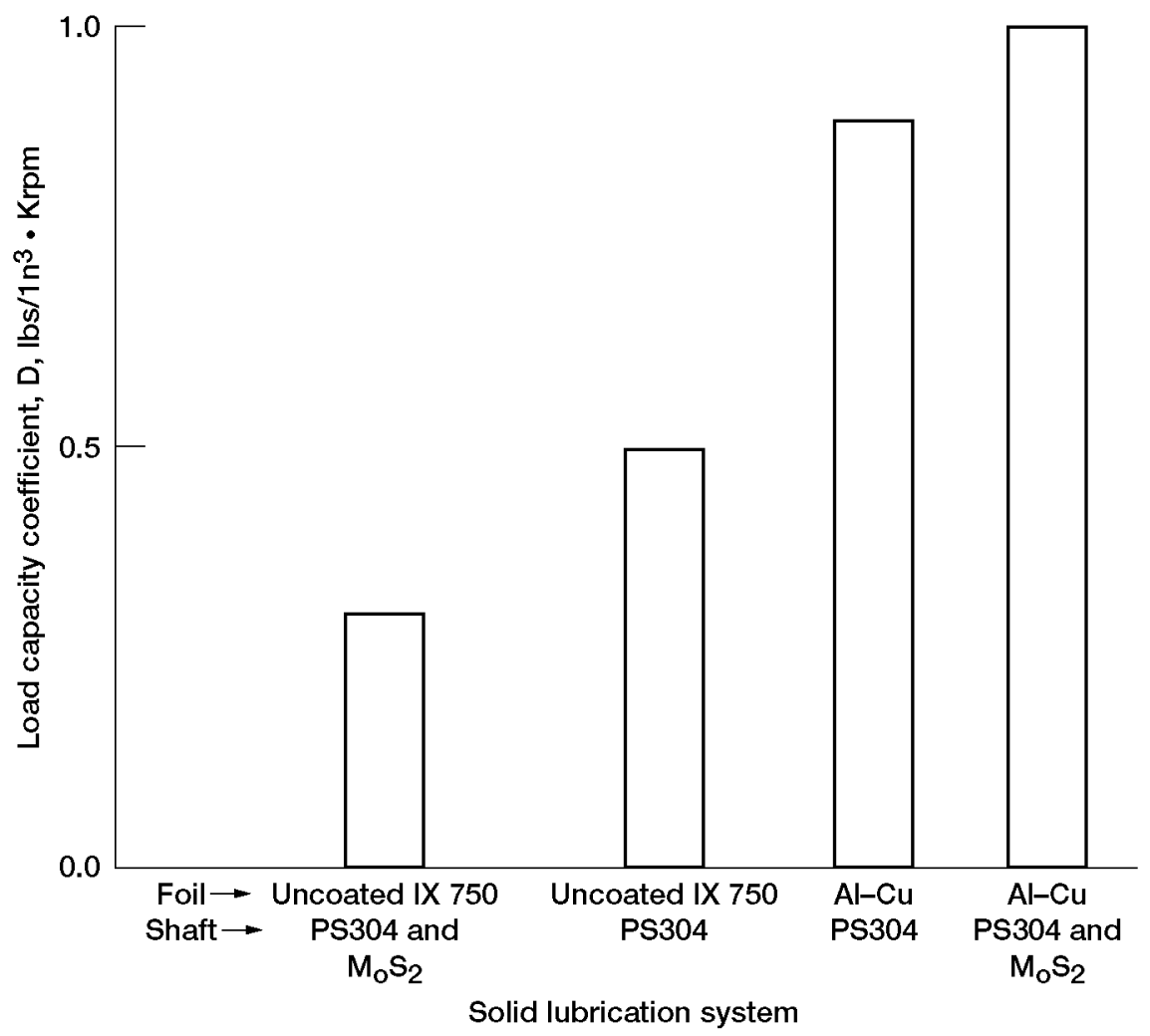

Figure 4.-Load capacity coefficient of as installed (not broken-in) foil bearing at $25^{\circ} \mathrm{C}$, showing the synergistic effects of wear resistant (Al-Cu) foil coatings, self lubricating shaft coatings (PS304) and sacrificial overlay solid lubricants $\left(\mathrm{M}_{\mathrm{O}} \mathrm{S}_{2}\right)$. 

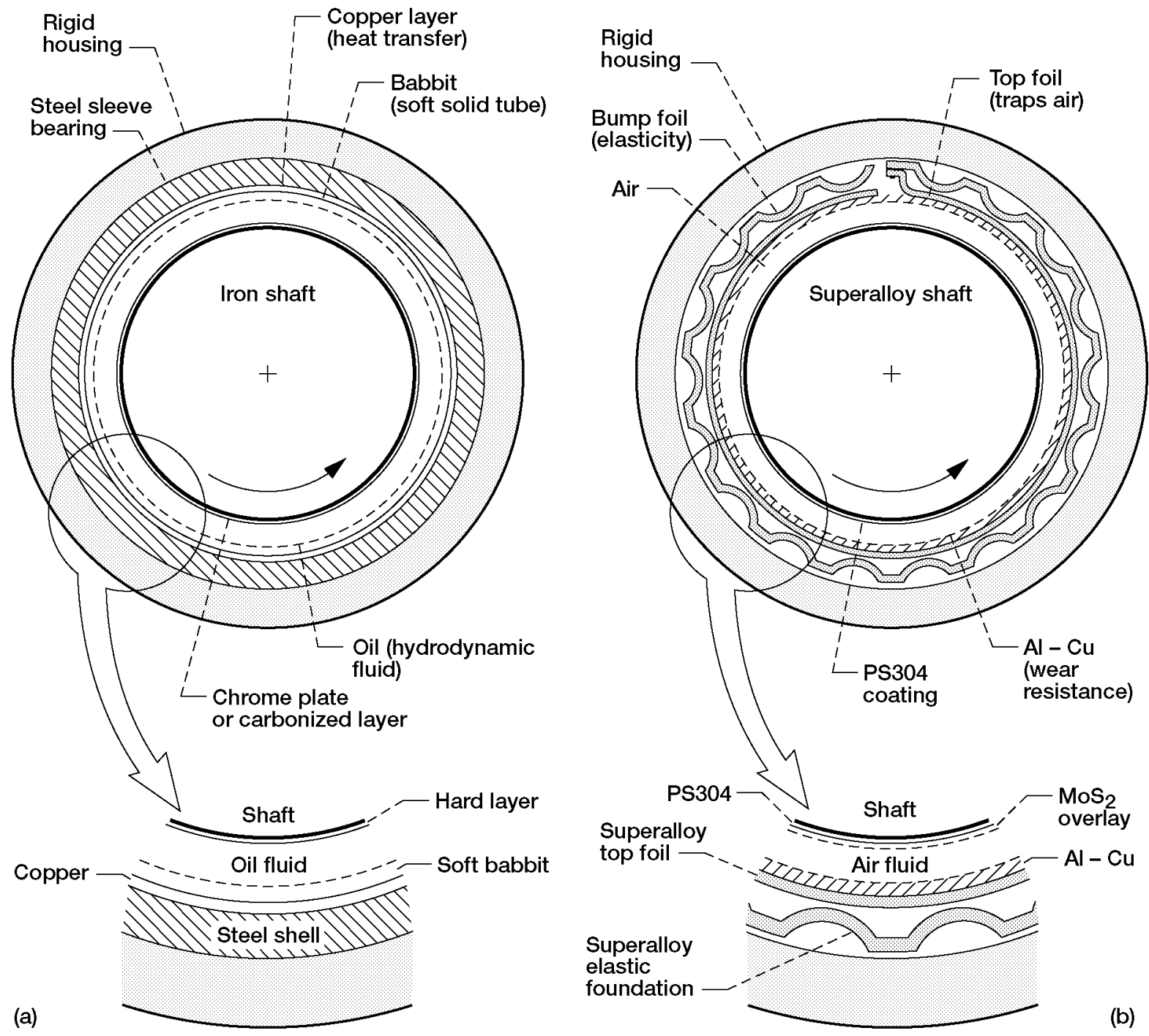

Figure 5.-Schematic representation of systems approach to bearing lubrication (a) convential oil lubricated bearing, (b) multilevel solid/gas lubricated foil air bearing. 


\section{\begin{tabular}{l|l|l} 
1. AGENCY USE ONLY (Leave blank) & 2. REPORT DATE & 3. REPORT TYPE AND DATES COVERED
\end{tabular}}

\begin{tabular}{|l|l|l}
\hline & October 2002 & Technical Memorandum \\
\hline
\end{tabular}

\begin{tabular}{l|l} 
4. TITLE AND SUBTITLE & 5. FUNDING NUMBERS
\end{tabular}

A Systems Approach to the Solid Lubrication of Foil Air Bearings for

Oil-Free Turbomachinery

6. AUTHOR(S)

Christopher DellaCorte, Antonio R. Zaldana, and Kevin C. Radil

WU-708-18-13-00

1L161102AH45

\section{PERFORMING ORGANIZATION NAME(S) AND ADDRESS(ES)}

National Aeronautics and Space Administration

John H. Glenn Research Center at Lewis Field

Cleveland, Ohio 44135-3191
8. PERFORMING ORGANIZATION REPORT NUMBER

E-13250

\section{SPONSORING/MONITORING AGENCY NAME(S) AND ADDRESS(ES)}

National Aeronautics and Space Administration

Washington, DC 20546-0001

and

U.S. Army Research Laboratory

Adelphi, Maryland 20783-1145
10. SPONSORING/MONITORING AGENCY REPORT NUMBER

NASA TM-2002-211482

ARL-TR-2867

\section{SUPPLEMENTARY NOTES}

Christopher DellaCorte and Antonio R. Zaldana, NASA Glenn Research Center; Kevin C. Radil, U.S. Army Research Laboratory, NASA Glenn Research Center. Responsible person, Christopher DellaCorte, organization code 5960 , 216-433-6056.

12a. DISTRIBUTION/AVAILABILITY STATEMENT

Unclassified - Unlimited

Subject Category: 23 12b. DISTRIBUTION CODE

Available electronically at htp//glts.grenasa.gov

Distribution: Nonstandard

This publication is available from the NASA Center for AeroSpace Information, 301-621-0390.

13. ABSTRACT (Maximum 200 words)

Foil air bearings are self-acting hydrodynamic bearings which rely upon solid lubricants to reduce friction and minimize wear during sliding which occurs at start-up and shut-down when surface speeds are too low to allow the formation of a hydrodynamic air film. This solid lubrication is typically accomplished by coating the non-moving foil surface with a thin, soft polymeric film. The following paper introduces a systems approach in which the solid lubrication is provided by a combination of self lubricating shaft coatings coupled with various wear resistant and lubricating foil coatings. The use of multiple materials, each providing different functions is modeled after oil-lubricated hydrodynamic sleeve bearing technology which utilizes various coatings and surface treatments in conjunction with oil lubricants to achieve optimum performance. In this study, room temperature load capacity tests are performed on journal foil air bearings operating at $14000 \mathrm{rpm}$. Different shaft and foil coating technologies such as plasma sprayed composites, ceramic, polymer and inorganic lubricant coatings are evaluated as foil bearing lubricants. The results indicate that bearing performance is improved through the individual use of the lubricants and treatments tested. Further, combining several solid lubricants together yielded synergistically better results than any material alone.

14. SUBJECT TERMS

Lubrication; High temperature; Coatings

15. NUMBER OF PAGES

21

16. PRICE CODE

\begin{tabular}{|c|c|c|}
\hline $\begin{array}{c}\text { 17. SECURITY CLASSIFICATION } \\
\text { OF REPORT } \\
\text { Unclassified }\end{array}$ & $\begin{array}{c}\text { 18. SECURITY CLASSIFICATION } \\
\text { OF THIS PAGE } \\
\text { Unclassified }\end{array}$ & $\begin{array}{c}\text { 19. SECURITY CLASSIFICATION } \\
\text { OF ABSTRACT } \\
\text { Unclassified }\end{array}$ \\
\hline
\end{tabular}

NSN 7540-01-280-5500 